\title{
Detection of plant viruses by PCR using group or virus specific primers (potyviruses, bymoviruses) ${ }^{1}$
}

\author{
by D. COLINET, J. KUMMERT, O. DUTERME and P. LEPOIVRE
}

Laboratoire de Pathologie Végétale, Faculté des Sciences Agronomiques, 13 av. Maréchal Juin, 5030 Gembloux (Belgium)

A combined assay of reverse transcription and the polymerase chain reaction (RT-PCR) utilizing degenerate primers derived from conserved regions in the genome of potyviruses was designed in order to amplify the $5^{\prime}$ terminal part of the coat protein cistron, which can differ greatly in length between distinct potyviruses. Amplification on total RNA extracted from one sweet potato clone from China yielded three fragments of different lengths, and sequence analysis of these fragments indicated mixed infections by three distinct potyviruses in the sweet potato clone investigated. Two degenerate primers were also designed in order to amplify the $5^{\prime}$ terminal part of the coat protein cistron of either potyviruses or bymoviruses. A third degenerate primer was selected from a region conserved in potyviruses and bymoviruses and used with primers specific for two different bymoviruses, barley yellow mosaic bymovirus (BaYMV) and barley mild mottle bymovirus (BaMMV). These primers allowed the identification of BaYMV and BaMMV barley plants from the field with single or mixed infection, and were used to clarify the etiology of a viral agent inducing mosaic symptoms on several barley cultivars considered so far as resistant to BaYMV and BaMMV. Amplification of fragments, including the variable $5^{\prime}$ terminal region of the coat protein cistron, thus provides a convenient method for the detection and characterization of potyviruses and bymoviruses, without fastidious preliminary work of separation and purification of the components of viral complexes.

\section{Introduction}

The polymerase chain reaction (PCR) has emerged as a powerful method for the identification of virus infections. The use of oligonucleotide primers corresponding to highly conserved regions of the viral genome has enabled the detection of plant viruses belonging to geminiviruses (Rybicki \& Hughes, 1990; Rojas et al., 1993), luteoviruses (Robertson et al., 1991) and potyviruses (Langeveld et al., 1991; Nicolas \& Laliberté, 1991; Colinet et al., 1994a).

We report here on the use of a combined assay of reverse transcription and PCR with degenerate primers for the detection and the characterization of potyviruses and bymoviruses as demonstrated by two examples concerning potyviruses infecting sweet potato, and viruses responsible for the yellow mosaic disease of barley.

The potyvirus group, which includes viruses responsible for severe economic damage to various crops, is characterized by flexuous rod-shaped particles, $680-900 \mathrm{~nm}$ long and $11-$ $15 \mathrm{~nm}$ wide, made up of about 2000 units of a single structural protein surrounding one molecule of single-stranded positive sense RNA of approximately 10000 nucleotides. The monopartite genomic RNA is expressed as one polyprotein which is processed by endogenous virus-coded proteases to give seven different proteins, schematically represented in Fig. 1.

Bymoviruses are distinguished from potyviruses by the fact that they are transmitted by a soil fungus to a limited number of cereal host plants, and that their single-stranded RNA genome is

${ }^{1}$ Paper presented at the EPPO Conference on New Methods of Diagnosis in Plant Protection, Wageningen (NL), 1994-01-25/28.

(C) 1995 OEPP/EPPO 


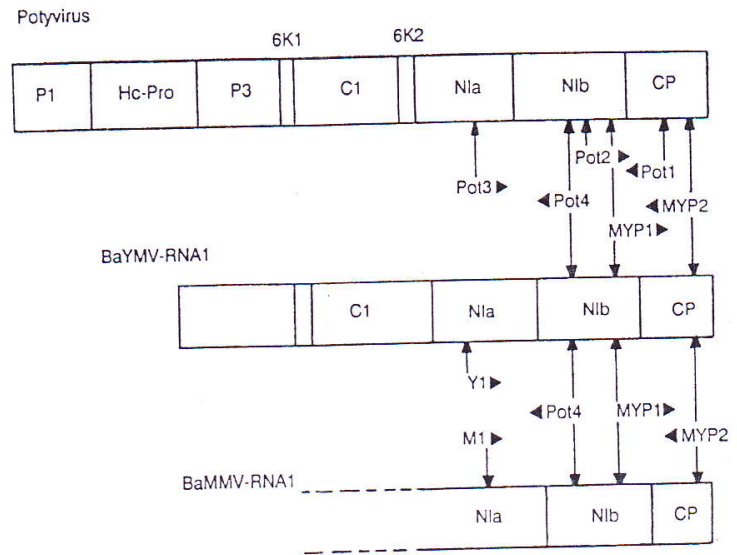

Fig. 1. Schematic representation of the genetic map of potyvirus and bymovirus (RNAl) genomes, showing the relative positions of the degenerate primers based on selected conserved regions (Pot1, Pot2, Pot3, Pot4, MYP1. MYP2) or regions specific for only one virus (M1, Y1).

Représentation schématique de la carte génétique du génome des potyvirus et de l'ARN1 des bymovirus et positions relatives des différentes amorces sélectionnées.

divided in two fragments, which are separately encapsidated into particles of 290 and $600 \mathrm{~nm}$. The genomic organization of RNA1 of bymoviruses is comparable to that of the $3^{\prime}$ terminal part of potyvirus genomic RNA (Fig. 1).

Sweet potato may be affected by five major potyviruses among which sweet potato feathery mottle potyvirus (SPFMV) is the most thoroughly characterized. SPFMV has been frequently identified worldwide as a component of viral complexes, and the ubiquitous nature of SPFMV complicates the isolation and identification of the other sweet potato viruses. The aim of our work was to detect, differentiate, and identify potyviruses infecting sweet potato in China.

Barley yellow mosaic disease results from the infection by one or both bymoviruses: barley yellow mosaic bymovirus (BaYMV) and barley mild mosaic bymovirus (BaMMV) which, generally, are simultaneously present in infected barley plants from the field.

The evolution of both viruses in the fields is complex, depending on the year, the stage of the culture, and the barley cultivar used. Moreover, mosaic symptoms were observed, in one field in Huccorgne on several cultivars considered șo far as resistant to BaYMV and BaMMV, and which did not react with monoclonal antibodies currently used in our laboratory for detection and identification of BaYMV and BaMMV in field plants (Kummert, 1993). Therefore, we decided to study the possible use of RT-PCR for the detection and the characterization of BaYMV and BaMMV isolates.

\section{Materials and methods}

\section{Virus isolates and plant material}

Several sweet potato clones from Guangdong Province (CN) (kindly provided by Dr Feng Zu Xia, Upland Crops Research Institute, Guangzhou) were maintained in Gembloux, under glasshouse conditions. The Chinese isolate of sweet feathery mottle potyvirus (SPFMV-CH; Colinet \& Kummert, 1993) was multiplied by mechanical inoculation to Ipomoea purpurea or $I$. nil. Type strain of sweet potato latent potyvirus (SPLV) was received from Dr Brunt (AFRC, 
Institute of Horticultural Research, Littlehampton, GB), and propagated in Nicotiana benthamiana and $N$. clevelandii.

Potato virus Y (PVY), used as a potyvirus reference strain was propagated in N. tabacum cv. Samsun.

Barley plants from two experimental fields, located in Gembloux and Huccorgne, were collected; cvs Arton and Express were collected at Huccorgne but only cv. Arton from Gembloux. Control material consisted of plants of the sensitive cv. Travelling, either healthy or mechanically inoculated with characterized isolates of barley yellow mosaic bymovirus (BaYMV) and/or barley mild mosaic bymovirus (BaMMV), and grown under controlled conditions.

\section{RNA extraction and cDNA synthesis}

Total RNA was extracted from leaves with symptoms by the method of Chirgwin et al. (1979). Single-stranded cDNA was synthesized from $5 \mu \mathrm{g}$ of total RNA using the Amersham cDNA

- ynthesis kit, and was diluted 10 -fold with sterile water.

Five $\mu l$ from these preparations were used for the PCR amplifications.

\section{PCR experiments}

PCR experiments were performed as described previously (Colinet \& Kummert, 1993). Thermal cycling scheme was: template denaturation at $94^{\circ} \mathrm{C}$ for $30 \mathrm{~s}$, primer annealing at $40^{\circ} \mathrm{C}$ (cycles $1-5$ ) or $50^{\circ} \mathrm{C}$ (cycles 6-37) for $1 \mathrm{~min}$, and DNA synthesis at $72^{\circ}$ for $2 \mathrm{~min}$. A final 15 min elongation step at $72{ }^{\circ} \mathrm{C}$ was performed at the end of the 37 cycles. For primers MYP1 and MYP2, annealing was at $40{ }^{\circ} \mathrm{C}$ for 10 cycles and at $50^{\circ} \mathrm{C}$ for 32 cycles; a secondary amplification was conducted in some cases, for 30 cycles at a primer-annealing temperature of $50{ }^{\circ} \mathrm{C}$, from $1 \%$ of the product purified from the first amplification by agarose gel electrophoresis and QIAEX gel extraction (QIAGEN). Amplification products were analysed by electrophoresis of $10 \mu \mathrm{l}$ from each reaction mixture in a $1 \%$ agarose gel in Tris-acetate-EDTA buffer (Sambrook et al., 1989). Bands were visualized by ethidium bromide staining.

\section{Cloning and sequencing of the amplified fragments}

Amplification products were extracted twice with phenol-chloroform, precipitated by addition of 0.1 volume of $3 \mathrm{M}$ sodium acetate, $\mathrm{pH} 5.8$, and two volumes of ethanol. The pellets were resuspended in $50 \mu \mathrm{l}$ of water and digested with BamH1 and EcoR1. After electrophoresis in $1 \%$ agarose gel, the bands of the expected lengths were excized and eluted with the QIAEX gel extraction kit from QIAGEN. The DNA fragments were directionally cloned into a BamH1EcoR1 site of the Bluescript plasmid. Recombinant plasmids were monitored for appropriate size inserts by cleavage with Pvull.

Nucleotide sequence was obtained either by subcloning the amplified fragments by cleavage with restriction enzymes or by using specific primers derived from the sequences. Doublestranded DNA sequencing by the dideoxy chain termination method was performed using the T7 DNA polymerase (Pharmacia) according to manufacturer's instructions.

\section{Dot-blot hybridization}

Digoxigenin labelling of cDNA probes, and hybridization on Hybond $\mathrm{N}$ membrane (Amersham) were performed using the DIG DNA labelling and DIG luminescent detection kits from Boehringer according to manufacturer's instructions.

(C) 1995 OEPP/EPPO, Bulletin OEPP/EPPO Bulletin 25, 289-299 


\section{Results and discussion}

\section{Design of PCR primers}

The amino-acid sequences of the polyproteins of several aphid-transmitted potyviruses (Allison et al., 1986; Domier et al., 1986; Lain et al., 1989; Robaglia et al., 1989; Johansen et al., 1991) and the amino-acid sequences of the coat protein of additional potyviruses (Shukla \& Ward, 1989) were compared. Four regions presenting a high percentage of homology, and encoded by codons of low degeneracy, were selected. Four degenerate primers that represented all possible nucleotides found in the respective potyviruses were synthesized (Colinet \& Kummert, 1993). A first set of primers (Potl and Pot2) was designed to amplify the $5^{\prime}$ terminal part of the coat protein cistron; the nucleotide sequence between the two other primers (Pot3 and Pot4) spans part of NIa and NIb cistrons of the potyvirus genome (Fig. 1).

Sequence data existing for the RNA1 of BaYMV (Kashiwazaki et al., 1990; Peerenboom et al., 1992) was compared with that of BaMMV (Kashiwazaki et al., 1992), and also with sequences of several potyviruses. This led us to select three other sets of primers (Fig. 1). Two degenerate primers, MYP1 and MYP2, were chosen in order to amplify the $5^{\prime}$ terminal part 0 . the coat protein cistron of both potyviruses and bymoviruses. The previously selected primer Pot4, which also corresponds to a region conserved in potyviruses and bymoviruses, has been associated with a second primer which is specific for either BaYMV (primer Y1) or BaMMV (primer M1).

In order to facilitate the subsequent cloning of the PCR products, sequences containing EcoRl or BamHl restriction sites were added at the $5^{\prime}$ end of the primers.

Table 1 gives the sequences of the degenerate primers used.

\section{Identification of distinct potyviruses in sweet potato with mixed infection}

Sequence comparisons and biochemical analysis showed that the $\mathrm{N}$-terminal of the coat protein of distinct potyviruses may vary considerably in length and sequence, whereas the C-terminal two-thirds of the protein are highly conserved. The degenerate primers Pot 1 and Pot 2 were thus specially designed to amplify the variable $5^{\prime}$ terminal part of the coat protein cistron in order to study the diversity and the identification of potyviruses infecting sweet potato clones from China

The combined assays of reverse transcription and PCR (RT-PCR) were carried out on total RNA extracted from leaves of $N$. tabacum $\mathrm{cv}$. Samsun showing symptoms of potato $\mathrm{Y}$ potyvirus used as the potyvirus reference strain, of $I$. purpurea with symptoms of a Chinese isolate of SPFMV (SPFMV-CH) alone (Colinet \& Kummert, 1993), and of two sweet potatc clones from China. Amplification with primers Pot 1 and Pot2 on PVY and SPFMV-CH yielded a 1.2- and a $1.35-\mathrm{kb}$ fragment, respectively (Fig. 2). Amplification on different sweet potato clones from China yielded the SPFMV-CH $1.35 \mathrm{~kb}$ fragment associated with one or two other fragments of 1.30 and $1.45 \mathrm{~kb}$ (Fig. 2), suggesting the presence of one or two other potyviruses in these sweet potato clones (Colinet et al., 1994a).

The 1.30- and $1.45-\mathrm{kb}$ amplified fragments were cloned into the Bluescript plasmid and partially sequenced. Comparison of the deduced partial amino-acid sequences derived from the amplified fragments with those of the $\mathrm{C}$-terminal region of the nuclear inclusion $\mathrm{b}$ protein and the N-terminal region of the coat protein of SPFMV-CH and of several other potyviruses lead us to conclude that the $1.30-, 1.35$ - and $1.45-\mathrm{kb}$ fragments were amplified from distinct sweet potato potyviruses in mixed infections (Colinet et al., 1994a).

Specific hybridization of the $1.30-\mathrm{kb}$ fragment with crude sap extracted from $N$. benthamiana, infected with the sweet potato latent virus isolate from Taiwan (SPLV), identified the corresponding virus as being closely related to SPLV. A $1.30-\mathrm{kb}$ fragment has been also

(C) $1995 \mathrm{OEPP} / \mathrm{EPPO}$, Bulletin OEPP/EPPO Bulletin 25, 289-299 
Table 1. Sequence of the selected primers

Séquence des amorces sélectionnées

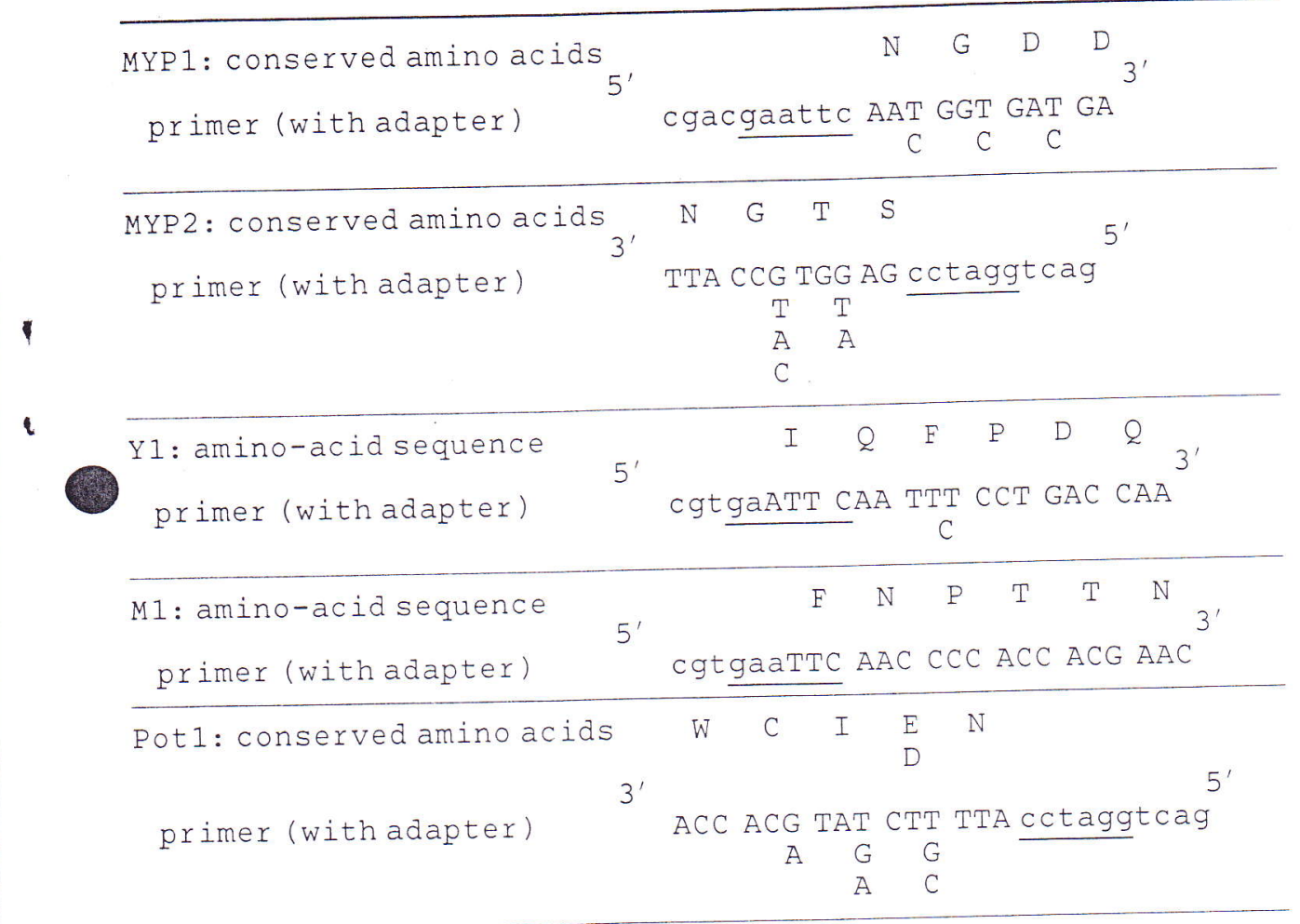

Pot 2 : conserved amino acids primer (with adapter) $\quad 5^{\prime}$ gacgatertc TGT GAT GCT GAT GGT TC C

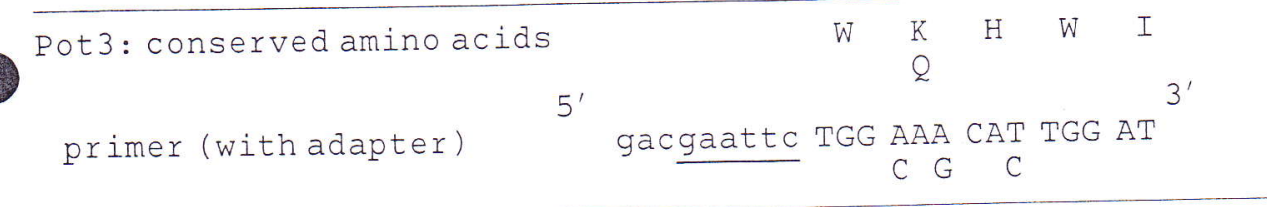

Pot4: conserved amino acids, W N G S L $3^{\prime}$ '

primer (with adapter) ACC TTA CCA AGA AAC cctaggtca $\begin{array}{lll}G & C & T \\ G & \\ & T\end{array}$ 


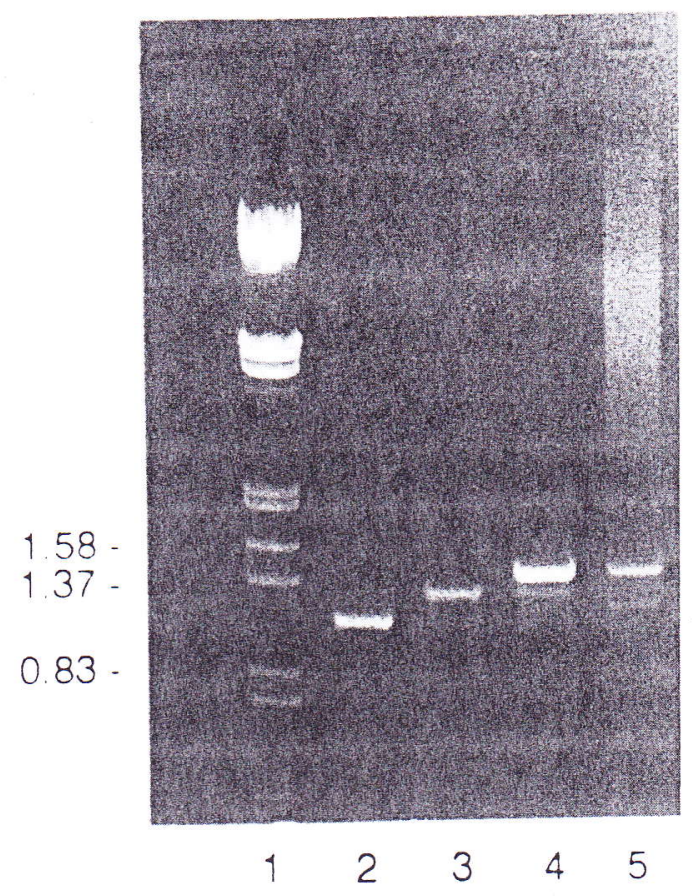

Fig. 2. Agarose gel stained with ethidium bromide, showing the results of amplification carried out on transcripts of total RNA from infected plants. Lane 1: DNA markers fragments with sizes (in kb) indicated on the left; lane 2: amplification on PVY-infected tobacco plants; lane 3: amplification on SPFMV-CHinfected I. purpurea; lane 4: amplification on sweet potato clone 530; lane 5: amplification on sweet potato clones 1 (from Colinet et al., 1994a).

Analyse des résultats d’amplifications réalisées à partir de transcrits d'ARN totaux de plantes infectées par différents potyvirus, par électrophorèse sur gel d'agarose et coloration au bromure d’éthidium.

amplified from SPLV-infected $N$. benthamiana and then cloned for partial sequencing (results not shown). The high level of homology observed in the $5^{\prime}$ terminal part of the coat protein cistron between SPLV and the $1.30-\mathrm{kb}$ product amplified from extracts of some Chinese sweet potato clones indicated that they were infected by a strain of sweet potato latent potyvirus (Colinet et al., 1994a).

Table 2. Expected size (bp) of amplified fragments obtained by PCR reactions for extracts of barley plants infected with BaMMV or BaYMV, using the three selected sets of primers

Taille attendue (pb) des fragments obtenus par RT-PCR à partir d'extraits de plantes d'orge infectées par le BaYMV ou le BaMMV, en utilisant les trois couples d'amorces sélectionnés

\begin{tabular}{lccc}
\hline & & Primers & \\
& M1-Pot4 & Y1-Pot4 & MYP1-MYP2 \\
\hline PVY* & - & - & 900 \\
BaMMV & 805 & - & 842 \\
BaYMV & - & $1128-1135$ & $960-962$ \\
\hline
\end{tabular}

* Potato Y potyvirus used as control for potyviruses/Potato Y potyvirus utilisé comme témoin pour les potyvirus.

(C) 1995 OEPP/EPPO, Bulletin OEPP/EPPO Bulletin 25, 289-299 


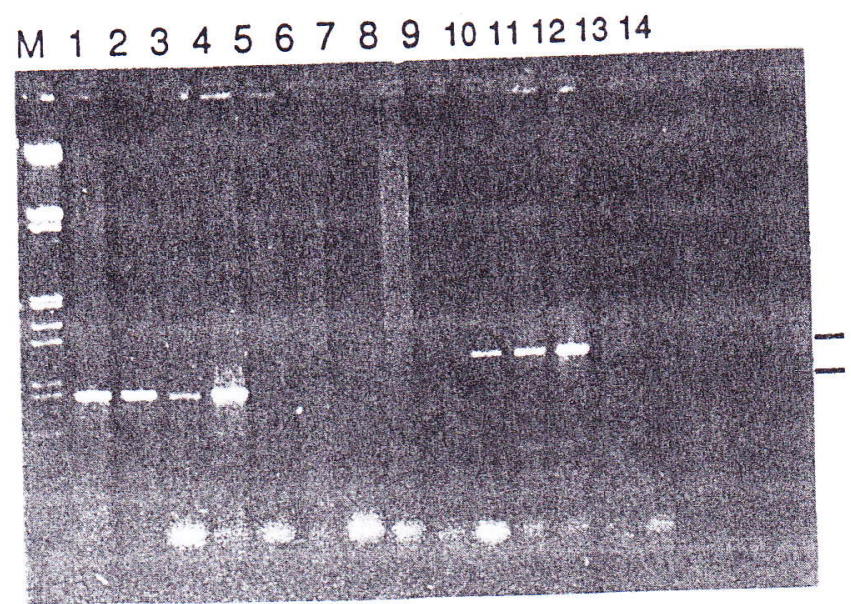

Fig. 3. Analysis of amplification products obtained from transcripts of total RNA preparations from healthy barley leaves $(6,13)$, leaves inoculated with isolates MF (BaYMV and BaMMV) $(1,8)$, MD (BaYMV alone) (2,9), or naturally infected leaves collected from cv. Arton in Huccorgne (3, 10), cv. Arton in Gembloux $(4,11)$ and cv. Express in Huccorgne $(5,12)$. Primers used for DNA amplification were M1 and Pot4 (1-7) or $\mathrm{Y} 1$ and Pot4 (8-14). M = molecular weight marker DNAs. Wells 7 and 14 received aliquots of PCR reaction mixture incubated in absence of template cDNA.

Analyse des produits d'amplification obtenus à partir de transcrits de préparations d'ARN totaux d'orges saines $(6,13)$ ou infectées par différents isolats de BaYMV et/ou de BaMMV (1-5, 8-12). Les amorces utilisées étaient Ml et Pot4 (1-7) ou Yl et Pot4 (8-14).

The virus corresponding to the $1,45-\mathrm{kb}$ amplified fragment still awaits further characterization, but sequencing of the coat protein gene indicates that this virus should be considered as being closely related to sweet potato feathery mottle potyvirus, though distinct (Colinet et al., 1994b).

\section{Characterization of mosaic virus isolates from infected barley plants from the field}

Analysis of published sequences existing for BaYMV and BaMMV allows us to estimate the expected size of the amplified fragments obtained by PCR reactions conducted with the three selected sets of primers (Table 2). Whatever the set of primers used, the size of the amplified product is different for BaMMV and BaYMV, which should allow us to develop tests for detection and differentiation of both viruses, even in the case of the mixed infection which generally occurs.

After optimization of the number of cycles and the hybridization temperatures for the different sets of primers, with cDNA preparations from healthy and mechanically inoculated plants (isolate MF containing both BaYMV and BaMMV), amplification reactions were conducted with the different barley origins described in 'Materials and methods'.

Fig. 3 shows that in the presence of primers M1 and Pot4, a DNA fragment of nearly $800 \mathrm{bp}$ is amplified from samples MD (inoculated with BaYMV only), MF, Arton Gembloux and Arton Huccorgne. The size of this fragment is compatible with that of $805 \mathrm{bp}$, expected for BaMMV (Table 2). We can thus suppose that these different samples are infected with BaMMV. By contrast, no DNA was amplified for the samples of cv. Express from Huccorgne (as for healthy barley).

When primers Y1 and Pot4 were used (Fig. 3), a DNA fragment of estimated size of $\pm 1130 \mathrm{bp}$ is amplified for preparations from Arton Gembloux, Arton Huccorgne and Express

(C) 1995 OEPP/EPPO, Bulletin OEPP/EPPO Bulletin 25, 289-299 


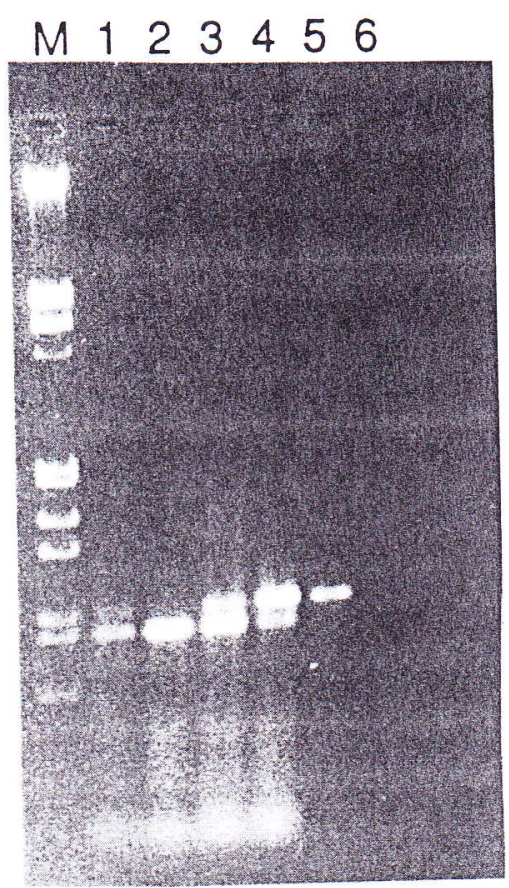

Fig. 4. Analysis of the products obtained after 2 successive PCR amplifications using primers MYP1MYP2. Transcripts of total RNA preparations from plants inoculated with MF (BaYMV and BaMMV) (1) and MD (BaYMV alone) (2) or of naturally infected plants of the cultivar Arton at Gembloux $(3,4)$ and of the cv. Express at Huccorgne (5). M = molecular weight markers DNAs. PCR reaction mixture incubated in absence of template DNA (6).

Analyse des produits obtenus après 2 amplifications successives à partir de transcrits de préparations d'ARN totaux de plantes d'orge infectées par différents isolats de BaYMV et/ou de BaMMV

Huccorgne. The size of this amplification product corresponds with that established on the basis of the sequences published for German and Japanese strains of BaYMV.

The hybridization temperature of primers MYP1-MYP2, being lower than that of primers Y1, Ml and Pot4, generates generally less efficient amplification reactions. Analysis of aliquots of reaction products shows indeed the presence of one or two fragments of estimated size of 840 and $960 \mathrm{bp}$, according to the sample considered.

A secondary amplification reaction conducted with 1 to $5 \%$ of the products of the primary amplification, after electrophoresis and purification by QIAEX, allows an increase of the annealing temperature during the first thermic cycles, with a correlative increase of amplification efficiency. Fig. 4 shows that, in this case, the different amplification products are clearly visible on the gel.

Analysis of sequences published for BaMMV and BaYMV indicates that the sizes of the amplification products obtained with primers MYP1 and MYP2 must be 842 and $960-962$ bp, respectively, for these two viruses. These are compatible with those we observed. We can thus conclude that samples of barley inoculated with MF, like those of cv. Arton collected at Gembloux and Huccorgne, are infected by a mixture of strains of both viruses (presence of two bands corresponding to \pm 840 and $960 \mathrm{pb}$ ). On the contrary, only BaMMV (one band at \pm 840 $\mathrm{bp}$ ) is found for samples of plants inoculated with MD, and only BaYMV (one band at \pm 960 $\mathrm{bp}$ ) is detected for symptomatic plants of cv. Express from the field of Huccorgne.

(C) 1995 OEPP/EPPO, Bulletin OEPP/EPPO Bulletin 25, 289-299 
All these results show that the use of the different selected sets of primers allows us to display all isolates of BaYMV and BaMMV from transcripts of total RNA preparations from infected barley leaves. They also suggest that the viral agent infecting cv. Express at Huccorgne is an isolate of BaYMV.

Part of the $960-\mathrm{bp}$ amplified fragment obtained for preparations from $\mathrm{cv}$. Express with primers MYP1 and MYP2 has now been sequenced. 464 nucleotides have been determined from the $5^{\prime}$ end of the coat protein gene, and the putative translated amino-acid sequence shares $98 \%$ homology with that published for the German isolate of BaYMV (Peerenboom et al., 1992).

These results confirm that the isolate capable of overcoming the resistance of cy. Express at Huccorgne is a BaYMV isolate.

In conclusion, amplification of fragments including the $5^{\prime}$ terminal region of the coat protein cistron provides a convenient method for the detection and characterization of potyviruses and bymoviruses, without fastidious preliminary work of separation and purification of the components of viral complexes.

\section{Acknowledgements}

This work was financially supported by the EU (project STD3 N) TS3-CT91-0013) and by IRSIA, Brussels (convention D 1/4-12261/5479A).

Détection de virus de plantes par PCR utilisant des amorces spécifiques pour des virus ou des groupes de virus (potyvirus, bymovirus)

Un protocole combinant la transcription inverse et la réaction de polymérisation en chaîne, utilisant des amorces dégénérées dérivées de régions conservées dans le génome des potyvirus, a été défini de manière à permettre l'amplification de la partie $5^{\prime}$ terminale du cistron de la protéine enveloppe qui peut présenter des différences de taille importantes pour différents potyvirus. L'amplification réalisée à partir d'extraits d'ARN totaux d'un clone de patate douce provenant de Chine a révélé la présence de trois fragments d'ARN de longueur différente et l'analyse des séquences de ces trois produits a montré que ce clone était infecté par trois potyvirus distincts. Deux amorces dégénérées ont également été conçues en vue de permettre l'amplification de la partie $5^{\prime}$ terminale du gène de la protéine enveloppe des potyvirus ainsi que des bymovirus. Enfin, une troisième amorce dégénérée, correspondant à une séquence conservée chez les potyvirus et les bymovirus, a été utilisée en combinaison avec des amorces spécifiques de l'un ou l'autre des deux bymovirus, BaYMV ou BaMMV. Ces amorces nous ont permis d'identifier le BaYMV et/ou le BaMMV à partir de plantes d'orge du champ; elles ont également été utilisées pour clarifier l'étiologie d'un agent viral capable d'induire des symptômes de mosaïque sur différents cultivars d'orge considérés précédemment comme résistants au BaYMV et au BaMMV. En conclusion, l'amplification de fragments d'acide nucléique incluant la partie variable $5^{\prime}$ terminale du cistron de la protéine enveloppe constitue une méthode adéquate pour la détection et la caractérisation des potyvirus et des bymovirus, ne nécessitant pas la séparation et la purification préalable des composantes du complexe viral.

\section{Детектирование вирусов растенин методом полимеразной цепной реакции синтеза с использованием групп вирус-специфичных праймеров (потивирусы, бимовирусы)}

Комбинированный анализ обратной транскрипции и полимеразной цепной реакции синтеза (ОТ-ПЦР) при использовании дегенерированных праймеров из сохраненных участков

(C) 1995 OEPP/EPPO, Bulletin OEPP/EPPO Bulletin 25, 289-299 
генома потивирусов был разработан для амплификации 5'концевого участка цистрона белка оболочки, который может значительным образом отличаться по длине между различными потивирусами. Амплификация полноразмерной РНК, выделенной из одного клона батата китайского сорта позволила получить три фрагмента различной длины. Анализ последовательности этих фрагментов вьявил наличие смешанных инфекций, вызванных тремя исследуемыми потивирусами батата. Были также получены два дегенерированньхх пран̆мера для амплификации 5'концевого участка цистрона белка оболочки потивируса или бимовируса. Третий дегенерированный праймер был выделен из сохраненной о6ласти потивируса и бимовируса и использован с праймером, специфичным для двух различньх бимовирусов, barley yellow mosaic bymovirus (BaYMV) и barley mild mottle bymovirus (BaMMV). Эти праймеры делают возможной идентификацию растений ячменя, пораженных ВаYMV и BaMMV на полях, зараженных одиночной или смешанной инфекцией. Они также были использованны для выяснения этиологии вирусного агента, включая мозаячные симптомы на нескольких культиварах ячменя, считавшихся до настоящего времени резистентными к BaYMV и BaMMV. Амплификация фрагментов, включая вариабельную 5'концевую область цистрона белка оболочки, предоставляет, таким образом, удобный метод детектирования и описания потивирусов и бимовирусов без трудоемкой предварительной работы разделения и очистки компонентов вирусных комплексов.

\section{References}

Aluison, R., Johnston, R.E. \& Dougherty, W.G. (1986) The nucleotide sequence of the coding region of tobacco etch virus genomic RNA: evidence for the synthesis of a single polyprotein. Virology $154,9-$ 20 .

Cuirgwiv, J Przybyla, A.. MacDonald. R. \& Rutter, W. (1979) Isolation of biologically active ribonucleic acid from sources enriched in ribonuclease. Biochemistry 18, 5294-5299.

COLNET D \& K L (SPFMV-CH) by the polymerase chain reaction with degenerate primers. Joumal of Virological Methods 45, 149-159.

Colinet, D., Kummert, J., Lepoivre, P. \& Semal, J. (1994a) Identification of distinct potyviruses in mixedly-infected sweet potato by the polymerase chain reaction with degenerate primers. Phytopathology 84, 65-69.

Colinet, D., Kummert, J. \& Lepoivre, P. (1994b) The complete nucleotide sequences of the coat protein cistron and the $3^{\prime}$ non-coding regioin of a newly identified potyvirus infecting sweet potato, as compared to those of sweet potato feathery mottle virus. Archives of Virology 139, 327-336.

Domier, L.L., Franklin, K.M., Shahabuddin, M., Hellman, G.M., Overmeyer, J.M., Hiremath, S.T., Siaw, M.F.E. Lomonosoff, G.P. Shaw, J.G. \& Rhoads, R.E. (1986) The nucleotide sequence of tobacco vein mottling virus RNA. Nucleic Acids Research 14, 5417-5430.

Johansen, E., Rasmussen, O.F., Heide, M. \& Borkhardt, B. (1991) The complete nucleotide sequence of pea seed-borne mosaic virus RNA. Journal of General Virology 72, 2625-2632

Kashiwazaki, S., Minobe, Y., Omura, T. \& Hibino, H. (1990) Nucleotide sequence of barley yellow mosaic virus RNA1: a close evolutionary relationship with potyviruses. Journal of General Virology 71, 26812790 .

Kashiwazaki, S., Nomura, K., Kuroda, H., Ito, K. \& Hibino, H. (1992) Sequence analysis of the $3^{\prime}$ terminal halves of RNAl of two strains of barley mild mosaic virus. Journal of General Virology 73 , $2173-2181$.

Kummert, J. (1993) Diagnostic et caractérisation des agents de la mosaïque jaune de l'orge par le test sérologique ELISA. Parasitica 49, 67-85

Lain, S., Riechmann, J.L. \& GARCIA, J.A. (1989) The complete nucleotide sequence of plum pox potyvirus RNA. Virus Research 13, 157-172

Langeveld, S.A., Dore, J.M., Memlink, L., Derks, A.F.L.M., Van der Vlugt, C.I.M., Asjes, C.J. \& Bol, J.F. (1991) Identification of potyviruses using the polymerase chain reaction with degenerate primers. Journal of General Virology 72, 1531-1541

Nicolas, O.\& Laliberte, J.F. (1991) The use of PCR for cloning of large cDNA fragments of turnip mosaic potyvirus. Journal of Virological Methods 32, 57-66.

1995 OEPP/EPPO, Bulletin OEPP/EPPO Bulletin 25, 289-299 
Peerenboom, E., Pröls, M., Schell, J., Steinbiss, H.H. \& Davidson, A.D. (1992) The complete nucleotide sequence of RNAl of a German isolate of barley yellow mosaic virus and its comparison with a Japanese isolate. Journal of General Virology 73, 1303-1308.

Robaglia, C., Durand-Tardif, M., Tronchet, M., Boudazin, G., Astier-Manifacier, S. \& CasseDELBART, F. (1989) Nucleotide sequence of potato virus Y (N strain) genomic RNA. Journal of General Virology 70, 935-947.

Robertson, N.L., French, R.\& Gray, S.M. (1991) Use of group-specific primers and the polymerase chain reaction for the detection and identification of luteoviruses. Joumal of General Virology 72, 1473-1477.

Rojas, M.R., Gilbertson, R.L., Russell, D.R. \& Maxwell. D.P. (1993) Use of degenerate primers in the polymerase chain reaction to detect whitefly-transmitted geminiviruses. Plant Disease 77, 340-347.

RyBYCKI, E.P. \& Hughes, F.L. (1990) Detection and typing of maize streak virus and other distantly related geminiviruses of grasses by polymerase chain reaction amplification of a conserved viral sequence. Journal of General Virology 71, 2519-2526.

Sambrook, J., Fritsch, E.F.\& Maniatis, T. (1989) Molecular Cloning: A Laboratory Manual. Cold Spring

Harbor Laboratory. New York (US).
ShukLa. D.D. \& WARD, C.W. (1989) Identification and classification of potyviruses on the basis of coat protein sequence data and serology. Archives of Virology 106, 171-200.

(C) $1995 \mathrm{OEPP} / \mathrm{EPPO}$, Bulletin OEPP/EPPO Bulletin 25, 289-299 